\title{
The Anglo-Indian architect Walter Sykes George (1881-1962), a modernist follower of Lutyens
}

Lutyens' system of proportion [...] began the link between us, by a chance action of mine, within the first year of my meeting him. He would never discuss it. It was intensely personal to him. [... He once] spoke to a group of students. One asked 'What is proportion?' and he answered 'God'.

Walter Sykes George to Hope Bagenal, January 1959. ${ }^{1}$

Walter Sykes George (1881-1962) (Fig. 1) was a remarkable Anglo-Indian architect. Obituaries in Indian and British journals cast him as a 'Renaissance' man: an artist, Byzantine archaeologist, architect, town planner, philosopher, historian, public intellectual, humanist, modernist, even an Indian nationalist. ${ }^{2} \mathrm{He}$ features prominently in one recent history of modern architecture in India, a rare accolade for an 'Anglo-Indian' architect - an architect born in Britain who practised and lived for much of his life in India. ${ }^{3}$ In spite of being one of New Delhi's most prolific architects, his name does not appear in Philip Davies's Splendours of the Raj, even though his colleagues Robert Tor Russell (1888-1972), Arthur Gordon Shoosmith (1888-1974) and Henry Medd (1892-1977) all do. ${ }^{4}$ Of all the members of the so-called 'Indo-British School of Architecture' who followed Herbert Baker (1862-1946) and Edwin Lutyens (1869-1944) to Delhi, he was alone in staying in his adopted country after Independence in $1947 .{ }^{5}$ His two greatest achievements are Kashmir House (1927-29), which he co-designed with Lutyens, and the rebuilding of St Stephen's College (1939-52), part of the University of Delhi, and one of India's most elite higher education establishments.

This essay, which builds on extensive research in the United Kingdom and time spent in India over the past three years, seeks to explain the interactions between George and Lutyens, who was arguably George's most important tutor. To throw light on this matter, detailed use will be made, for the first time, of George's correspondence with Anne Shearer (1952), a family friend, and with Hope Bagenal (1959), the architectural theorist and acoustician. ${ }^{6}$ As Gavin Stamp has 
said, it was Lutyens who was the most important influence on the 'Indo-British School', and those who 'responded to the spirit rather than the letter of [his] example, learning from his ability to abstract, to simplify Classical forms while never losing a powerful, sculptural sense of mass' produced, with hindsight, the most successful buildings. ${ }^{7}$ Considerable attention will also be focused on George's assimilation with his adopted country, through his understanding of the necessities of the Indian climate and his comprehension of native customs and how architecture should, in his view, respond to them. Finally, some observations on George's position in the history of post-Independence Indian architecture will also be offered, as well as an overall evaluation of his output.

Walter George was born on 24 February 1881, into an East Anglian family of architects and carpenters. In 1901 he enrolled at the Royal College of Art, where he studied under William Lethaby (1857-1931) and Arthur Beresford Pite (1861-1934). He travelled widely: Florence in 1902; Italy and France in the winter of 1903; Greece, Egypt, Turkey, and elsewhere in 1906; Macedonia and Turkey in 1909; Egypt, Sudan, and elsewhere in 1912-13. ${ }^{8}$ His intense interest in Greece and Turkey is, in particular, testament to his work at this time as an archaeologist. ${ }^{9}$ Between 1908 and 1915, he also exhibited five paintings at the Royal Academy. One of these, Afterglow (c. 1908), was later engraved by his wife Lena, whom he had married a few years earlier. ${ }^{10}$ It shows the buildings of the Acropolis lit dramatically, and anticipates a remark he was to make more than forty years later, when he wrote to Anne Shearer and commented that if you want to know what real architecture is, go and look at the Parthenon'. ${ }^{11}$ His love of Classical architecture, it will be shown, was also to serve him well in his interactions with Lutyens. The culmination of his work as an archaeologist was his detailed, meticulous study of the church of Hagia Irene in Istanbul, dating from the fourth century onwards. ${ }^{12}$ His drawings and an 
accompanying text were published in 1912, and a reviewer for the Burlington Magazine described his work as 'reliable' and as a 'model of what such a record should be'. ${ }^{13}$ He later described his archaeological years as perhaps 'the happiest in my life'. ${ }^{14}$

After returning to England, George was involved in the design of Whiteley Park Village (c. 1914) in Surrey. The Park, for 'thrifty old people', was funded by a legacy of $f 1$ million left bequeathed by William Whiteley on his death. ${ }^{15}$ The layout, as Nikolaus Pevsner and Ian Nairn have written, is 'as formal and symmetrical as that of an ideal Renaissance town', and the overall style is akin to that of Hampstead Garden Suburb, which was being built at around the same time. ${ }^{16}$ The East Avenue cottages were the work of Ernest Newton (1856-1922), then president of Royal Institute of British Architects. ${ }^{17}$ George must have already been in Newton's office at this stage, as there are sketches by him of these cottages in his papers in the R.I.B.A., together with notes about excavations, the development's radial plan, and so on. ${ }^{18}$ This, however, was probably the only architectural work that George was involved with in England, for in 1915, refused by the Army on account of his impaired vision, he departed for Delhi, then one of the largest construction sites in the world. ${ }^{19}$

George went to India specifically to oversee the construction of Baker's North Secretariat, and to be his representative in India during his long period of absence each year. ${ }^{20}$ Later on, however, George was effectively to deny his involvement with Baker and his role in this work. When he received a C.B.E. in 1961, the queen remarked that he had 'built the Secretariats' but George replied that he had come to India 'to help Lutyens to see the whole of Delhi through [and] to see $[\ldots]$ it was done as he intended. ${ }^{, 21}$ According to Stamp, however, Lutyens's representative in India during 1915-20 was John Greaves (Fig. 2), who was subsequently replaced by Shoosmith. ${ }^{22}$ Why George choose to revise this bit of his history can probably be related to the view expressed by his contemporary Medd, who travelled to India in 1919 to become Baker's second 
representative, and this was that 'Lutyens was the only real artist'; ${ }^{23}$ for, as Stamp has commented, 'even when architects worked for Baker, it was usually Lutyens that they revered. ${ }^{24}$ Nevertheless, George must have gained an immense amount of experience from his connections with Baker, and they may have become close as a result of their common admiration of Greek architecture. ${ }^{25}$ George had a 'large staff of draftsmen working under him' in Delhi, where prominent assistant architects often gained quick rises in status, and this was a rapid advance on his career in England. ${ }^{26}$ While Baker and Lutyens could escape the hot season and monsoon which E.M. Forster (who was also in India at this same time) called 'a common burden' and a 'herald of horrors' - George was often out in the midday sun dealing with all varieties of practical problems, as well as overseeing the production of an almost unimaginable number of drawings. ${ }^{27}$

Although George was to learn more from Lutyens than Baker as the years progressed, his position as one of Baker's representatives was not without its rewards, and there were three in particular. First, he had an opportunity to apply Classical architecture on a monumental scale, and to learn how to master 'mass, line, proportion' ${ }^{28}$ Secondly, he gained knowledge of Indian building materials - in particular the 'deep burnt rhubarb' and 'rosy cream' sandstones that Robert Byron had lauded, although the problems with their weathering may have eventually caused him to prefer using quartzite and brick. ${ }^{29}$ Thirdly, through preparing drawings for Baker, he became familiar with the Mughal architectural style and its most characteristic features, such as the chujja (overhanging cornice), the chattri (a type of airy cupola) and the jaali (a perforated stone screen). However, it was seeing Lutyens's Viceroy's House (now Rashtrapati Bhavan) being built during the 1920s (Fig. 3) that must have been the most affecting experience in George's development as an architect. It was certainly Lutyens for whom George - later in life was unbounded in his praise, calling him a successor to Wren, to Michelangelo, and even to Leonardo da Vinci..$^{30}$ 
George also became involved in landscape planning at this time. The roadside planting of trees in the centre of the city was being overseen by Lutyens and William Robert Mustoe (1878-1942) who, during the winter months, would have breakfasted together and agreed the kinds of tree to be planted. ${ }^{31}$ For the rest of the year, however, Mustoe worked instead with George. ${ }^{32}$ It could be said that landscape planning is a more mundane activity than the 'high game' of architecture, but the theatrical layout of Lutyens's city with its interaction of vistas, and the need for shade from the harsh Indian sun, made this work essential to the overall success of New Delhi. Thus his involvement in this work brought George closer to Lutyens, personally and also intellectually, just as it lead to a friendship with Mustoe, whom he accompanied on Sunday drives to plant Prosopis Juliflora in the city's outskirts. ${ }^{33}$ George was later to produce a design of his own in laying out, in 1926, a twenty-eight acre garden for the British Residency in Kabul, Afghanistan. ${ }^{34}$

George ended his connection with Baker in 1924, having set up his own practice in Delhi in 1920. ${ }^{35}$ The nine years with Baker had given him much, but it was to be a while before New Delhi would have its full impact on George's own architectural output. The uninspired quality of his early works can be attributed, quite often, to a shortage of money or time, but it also reflected an absence, at this early stage, of a coherent response to all that New Delhi provided him. The façade of George's Maiden's Hotel in Delhi (1920) (Fig. 4) can be seen as representative of this early period. ${ }^{36}$ According to Medd, the 'rebuilding of the front' of Maiden's, then one of the most popular hotels for European travellers, was undertaken with the help of a C.J. Brandon. ${ }^{37}$ Its dazzlingly white façade is thoroughly immersed in the neo-Classical tradition and the engaged Tuscan colonnade is similar to what his colleagues, especially Russell, were designing at this time. The only 'Indian' features are the heavy, bracketed 'Hindu' arches of the carriage porch, each made up of six gentle 'S'-shaped corbels - derived perhaps from Baker's design for the niches that punctuate his great monolithic wall at the base of Raisina Hill (eventually completed $c$. 
1931). ${ }^{38}$ Maiden's Hotel certainly has architectural charm and dignity, but it was a rushed job (completed in six months), and does not show any great originality, instead remaining within the stuccoed, neo-Classical tradition which was then at its height in Delhi and which had also defined a century of building beforehand in Calcutta. ${ }^{39}$

George first met Lutyens when he was 35, his character already formed, his interests established, his independent career about to start. ${ }^{40}$ Lutyens was 47 , balding, the enfant terrible genius of British architecture. He was preoccupied with New Delhi's every detail to 'the $128^{\text {th }}$ part of an inch', saying all kinds of foul things about Baker, visiting India for a few months every year, and, according to Stamp, becoming 'increasingly obsessed by the subtleties of geometry' and 'the emotional power of pure monumental form, comprehensible only in the classical tradition'. ${ }^{41}$ This style has been identified by Christopher Hussey, not without controversy, as Lutyens's 'Elemental Mode': a distillation of the Classical language of architecture that was repeated until only pure form remained, to which, he said, Lutyens added 'the subtleties of entasis, visual compensation, and curvature by means of a basically simple but complex geometry, that was likewise often implicit, not expressed'. ${ }^{42}$ The style was to appear all over Delhi, in gateways and monumental arches, and in the dome of the Viceroy's House and its Mughal Gardens, and it is to be seen, too, at the Thiepval Memorial (1927-32) in northern France, and in his drawings for the (mostly unexecuted) Cathedral of Christ the King, Liverpool (1929-41). Although George's personality was indeed well formed by this time, Lutyens's 'Elemental Mode' was nevertheless to have a profound impact on him. It was not an immediate one, and was only to reach full bloom at Kashmir House, which will be discussed shortly. This impact was accompanied by a close friendship with Lutyens. As George recounted later to Bagenal:

[Lutyens] was a very quick reader of other men [...] and he fairly soon began to recognise a sincerity of mind equal to his own, for under all that mask of boyish naughtiness there lay a profound sincerity. [...] Another thing that brought us together within a year (or less) was the discovery in each other of a profound interest in the question of proportions, a mystery on which he would talk only little and generally. ${ }^{43}$ 
In another letter to Bagenal about this friendship, George spoke of Lutyens's design practices: It began the link between us, by a chance action of mine, within the first year of my meeting him. He would never discuss it. It was intensely personal to him. [...] He knew certain dimensions and relationships, and used them broadly, but the design was instinctive, by feeling, the rules were only a check. [...] He could, and did produce a quick sketch with a string of dimensions, and say 'Draw it out'. When drawn out, he adjusted, by eye, and final dimensions were then determined by establishing them by simple mathematical relationships, geometrically arrived at during the process of making re-drafts. [...] Over and over again, I have done the same thing. Drawn something out, was dis-satisfied and altered where the eye was displeased, and then applied a scale of proportions produced geometrically, and found it coincided with what I had done .[...] You will (or may) think all this useless mysticism, and scarcely worth discussion. [...] Be very careful in quoting me on this. I have put it into words for no one but you. [...]As with Lutyens, it is much too intimate to speak of freely. Such systems have run right through history, and have always been esoteric, except to such as Vitruvius and many others up to the moderns, including Le Corbusier. $^{44}$

This was not blinkered admiration for Lutyens, since, later in life, George was often to criticize him; it was rather the discovery of a shared and fascinating mystery, and the rationalisation of it in a rather esoteric manner. He was later, in 1952, to write about the Parthenon in similarly psychological terms, suggesting a continued debt to Lutyens, as well as to other intellectual writers of his generation including Byron and Geoffrey Scott:

These huge column-drums $[\ldots]$ please not only the physical eye, but the intellectual eye that askes for proportion, following a law, so that every part, and every mass, should have exact geometrical relations of the most subtle kind, one $[\ldots]$ the universe undoubtedly has. Of what $[$ is $]$ all this madness $[\ldots]$ you may well ask, but I thoroughly believe it is not madness, but that in some ways we cannot fathom [...] a human and psychological reaction to all this. Pure mysticism you will say. ${ }^{45}$

When one considers the progression of George's architectural style, moreover, it is tempting to see his 'close communion of mind' with Lutyens, to quote his friend J.B. Fernandes, and their geometrical mysticism, as a kind of intellectual advance that took place at some point in the late 1920s. ${ }^{46}$ Perhaps this is the case: no other external influence, not even his later following of 
international trends such as Expressionism and Modernism, had such a large impact on his output as an architect.

This interest in geometry had profound implications. The two men shared a similar work ethic: Lutyens was known to say 'Don't talk, draw it!' to some of his assistants, a call George echoed later in life when he remarked that 'an architect should talk with his pencil', and not show signs of “"stickiness" or pretence'. ${ }^{47}$ This interest in geometry was also shared by two of Lutyens's most brilliant followers in Delhi, Medd and Shoosmith. According to Stamp, Medd used the same proportional system that Lutyens had employed for the Thiepval memorial for his interior of Delhi's Roman Catholic Cathedral (1927-35), whilst Shoosmith applied the principles of the 'Elemental Mode' to the nave-and-tower composition of a traditional English parish church for his St Martin's Garrison Church (1928-30) in Delhi's cantonment area. ${ }^{48}$ Arguably, George took the application of geometric principles still further in his post-Independence work, where (as we will see) he pushed it to its inevitable conclusion in works conceived in a kind of abstract Classicism bordering, it may be argued, on a Modernist aesthetic. When he described these later works as 'aniconic, that is, it does not represent anything but pure form', this was inherently the same 'pure monumental form' as employed by Lutyens at Thiepval, Liverpool and the Cenotaph in London. ${ }^{49}$

Most of George's buildings of the 1920s are antecedents to this 'pure form'. Some have been demolished in the past few decades, while for some we must postulate approximate construction dates, as no documentary records have yet been located. All are noteworthy but minor in the overall scope of his career. In 1927 he designed Jind House, Delhi. ${ }^{50}$ Now demolished, a surviving photo shows the pared-down Classicism which was an assumed part of George's early works. The main façade - an arcade framed by a series of very plain pilasters and an architrave — shows George's curious interest in the circle as a decorative motif. Where one might expect to 
find a keystone, George instead placed a protruding circle in the architrave above it, a motif which he may have borrowed from the carriage porches of Baker's Council Chamber, Delhi (completed c. 1931), or some of Lutyens's buildings, in particular the India Arch, Delhi (also completed c. 1931). In another project, Bhawalpur House, Delhi (1927) (Fig. 5), now the National School of Drama, the circle motif reappears - here on the abacuses of the Doric capitals (Fig. 6) - and from this time on the majority of his buildings were to feature the circle motif somewhere - whether hidden in an interior, or proudly punctuating a carriage porch. The Bhawalpur house also features the bracketed arches which he had used on Maiden's Hotel, and a (rather poor) stucco copy of Lutyens's monumental Viceroy's House dome. The use of the dome, itself an interpretation of the Buddhist (rather than Hindu or Muslim, and so politically neutral) dome at Sanchi, Madhya Pradesh (c. 250 BC), was a common feature too of Maharajah's houses in Delhi, keen always to associate themselves with the perceived authority of the viceroy and the Raj. ${ }^{51}$

If George had died in 1928, or simply gone home, he would scarcely have been a notable figure in the history of Delhi's architecture. As it was, from this time on, we see the flowering of an architectural vision that followed, to some degree, from his friendship with Lutyens. No better opportunity was there to display this new vision than at Kashmir House on Delhi's Prithviraj Road (1927-29), which he actually co-designed with Lutyens (Fig. 7). ${ }^{52}$ The project's history is complicated, not least because it is hard to disentangle the exact role played by each architect, and because the patron, a wealthy Hindu banker, Sultan Sing, died before the house was completed, and left it to his uninterested son, who sold it on to the Maharajah of Patiala. Following a period of neglect, and the arrival of Independence (1947), the house passed into the ownership of Kashmir State, whereupon it found its current name. ${ }^{53}$ What can be established is that Sing first asked Lutyens for a design, which was supplied by his office in 1927. Then, for reasons unknown, he approached George and asked for an alternative scheme, remarking 'I 
would like you to build a house for me to show what an Indian gentleman's house should be'. After realising Lutyens was already involved, George at first refused the commission, and he later recounted what happened next:

During the next cold-weather (1927-28) [the banker] saw Lutyens, and told him he thought I would understand better how an Indian gentleman liked to live. [...] The banker wished to entertain in western fashion, and to have western guests to stay with him, while he, and his family, lived in orthodox Hindu fashion, and he gave dinners in that fashion. ${ }^{54}$

Here, then, we have an indication of George's increasing integration into Indian culture and customs, which was to colour his later career, with the result that at least one modern historian of Indian architecture has praised his works for being 'compatible with [Indian] habits, ways of life [and] culture'. ${ }^{55}$ A year later, in 1929, the two architects were still working on the project together; but Lutyens eventually tired of his patron's continual prevarications, and, according to George, said that 'I shall never be able to get on with this man: will you be good to me and take it over yourself ${ }^{56}$ In fact, in his private correspondence with wife, Emily, Lutyens was more direct:

I have written saying I cannot let my name be attached to Sultan Sing's house \& George had better do it. Every time I see him he changes his mind [and] he has answered with a pathetic appeal to me. [The Indians] don't understand that they can do anything, alter anything, and yet call it a Lutyens house. ${ }^{57}$

Thus it was that George took full control of Kashmir House, and brought the project to fruition. Almost all the important rooms are located on the ground floor - the first floor, which is set aside for the bedrooms, having a footprint less than one-quarter the size of that below it (Figs. $\mathbf{8}$ \& 9). It is the on the ground floor too where the geometrical principles adopted for the plan are most evident, the bedrooms and loggias being squares and of equal dimensions, the drawing and dining rooms exactly are twice this size, and the width of the hallway exactly half. This floor is laid out with an enclosed courtyard attached at one side to a long corridor that runs the house's entire length, connecting the 'western' and 'orthodox' dining rooms with the drawing room, 
bedrooms (Fig. 10). There are no less than four loggias, and the 'Hindu' and 'English' kitchens are kept in separate wings, presumably to keep foods (meats, especially) separate; a Puja room for daily worship; and the north-east loggia allows a more private entrance for the family and their servants, in contrast with the north-west porch or the south-west loggias, which open onto a garden. George's influence in this plan was significant, and he recorded that 'Lutyens planned rather stuffily, because his desired visual effects controlled his design more than the plan, so some "opening-up" was necessary, a comment which perhaps refers to the kitchen wings, or the entrance porch.$^{58} \mathrm{He}$ also said that the 'parti pris' (i.e. the overall conception) for the entire design was Lutyens's, and that 'out of loyalty to him, and to the idea', he was 'bound to keep it', but that the 'handling throughout' was his and that he considered himself 'free to modify or re-design wherever practical craft, or aesthetic reasons required. ${ }^{59}$

The exterior is almost entirely brick - unadorned, austere - with the exception of the chattris, entrance porch and columns. Small windows (and unusually thick walls) are used deliberately to counter the effects of the hot climate. Further to this, the windows in the recessed, terrace-like first floor are sunken, so it is difficult to see into them from the entrance yard or surrounding gardens. George said he was aware of what Frank Lloyd Wright was doing at this time, but 'that could not be done here, because [English and Hindu customs] require privacy, and there is little privacy in Wright's houses. ${ }^{60}$ In addition, the use of a courtyard and south-facing loggias mean that all the ground floor bedrooms, including the principal ones, are shaded and lit indirectly. ${ }^{61}$

Throughout the building, but most spectacularly on the south-west trio of loggias, we see the use of paired and fluted Doric columns, in this case without circles on the abacus, but with matching polygonal astragals and a slight entasis. These columns support serlianas with clever brick jackarches, a device perhaps outside Lutyens's lexicon, but something George could have picked up from the arcaded courtyards of Baker's Secretariats, or some Swedish buildings of the time, such 
as Ragnar Östberg's Stockholm Town Hall (1909-23). ${ }^{62}$ More in character with Lutyens are the three chattris on the roofline above the entrance porch, which, with their brickwork indentations, play a geometrical game and double the overall rhythm of the façade. Similar indentations appear on the loggia façade.

So far only brief mention has been made of the porch (see Fig. 7), but this is undoubtedly the building's single most striking feature, and it is the most conspicuous indication of George's assimilation of the possibilities of reinforced concrete. In fact, he proudly described it as 'the first of its kind in New Delhi, or of any I know'. Aware of the advances in the use of the material made by the Swiss engineer Robert Maillart (1872-1940), he saw that the true potential of lightweight reinforced concrete was in its use in shell-like forms. This is exactly how the porch's hood is formed:, which then has-a structure of four curved beams, shaped like those of an aircraft wing. It is supported by a combination of cantilevering and by two brick piers. George later wrote that he regretted not pushing his design 'one step further', by removing the need for the piers and having the hood supported by the wall alone. This would have involved making the hood L-shaped in cross-section, so it would be reliant on the weight of the brick wall above it, which would have allowed the hood to hover above the doorway. Nevertheless, the porch is an exciting feature for its time, and contributes in no small way to the façade's horizontal aesthetic. George did not use reinforced concrete as a substitute for stone or brick but saw the potential it alone offered for new shapes, describing it as a 'plastic material' that must be used 'thin, and bent'. He also recorded that when Lutyens first saw the house in December 1931 he was 'keenly interested', before modestly noting that Lutyens's 'reactions are recorded elsewhere, and need not be repeated here'. ${ }^{63}$ This was presumably a reference to a remark recorded by Fernandes: Lutyens said ‘George you have given me a new experience. I am seeing myself through another man’s eyes. [...] Many have tried to copy me; many to imitate me; but you are the only man who has ever revised me. ${ }^{64}$ 
The importance of this remark is undeniable. For George and his colleague Shoosmith have been credited by two modern-day scholars, Kazi Khaleed Ashraf and James Belluardo, for introducing into Delhi the 'brick and concrete aesthetic' that continues to define some of its 'best architecture'. ${ }^{65}$

In working on this building, George was certainly indebted to Lutyens, but he may have been responding to other influences too. One of these, for example, could well have been Shoosmith's St Martin's Garrison Church, which was built around the same time, but there could have been others too, including some of the impressive mausolea belonging to Delhi's Mughal heritage. In viewing Kashmir House from the south-west (see Fig. 10), for example, its debt to the Tomb of Humayun (c. 1570) is apparent in the bold massing of its ground-floor loggias and first-floor bedrooms, and in the stepping back of the façades. George may have also been influenced by Europe's brick Expressionism, and buildings such as Willem Dudok's Town Hall at Hilversum in Holland (1924-31), which has a similarly bold and unadorned massing. ${ }^{66}$ Dudok was also active in India in the 1930s, and so George could easily have known of his work. Other possible sources would include Josef Franke's buildings in Gelsenkirchen, Germany (of which more later), and even publications such as Hugh Ferriss's The Metropolis of Tomorrow (1929). ${ }^{67}$ The illustrations by Ferriss of 'step-back buildings', where simple rectangular plans rise to become increasingly complex elevations, are reminiscent both of Kashmir House and of George's later project for St Thomas's Church. ${ }^{68}$

Subsequent schemes by George show his increasing willingness to 'revise' and advance the principles of Lutyens's 'Elemental Mode'. In Jodhpur he built the Law Courts, Umaid Hospital, and Umed Club, all probably of the mid-to-late-1930s, to judge from their similarity with George's best known building, his St Stephen's College in Delhi (to be discussed shortly). ${ }^{69}$ The Law Courts and Hospital (Fig. 11) are built from two types of locally-sourced stones, basalt and 
sandstone, whilst the use of chattris and bracketed arches is particularly appropriate in Jodhpur, since the city is located in Rajasthan, the heart of Mughal India. Apart from the Lutyensque geometrical massing of forms, which so define these buildings, one other feature is worthy of special note. This is the use again of the circle motif, most strikingly on the Hospital's carriage porch and George may have been aware of the use of this feature in ancient Indian architecture, such as at the seventh-century Hindu temple at Aihole, Karnataka. ${ }^{70}$

George set the tone for St Stephen's College in his St Thomas's Church in the Delhi suburb of Paranganj (1929-32). ${ }^{71}$ It dates from the year after Shoosmith had designed St Martin's, one of the great architectural triumphs of its time. ${ }^{72}$ It rather fittingly take up Shoosmith's abstract aesthetic, since St Thomas's was a low-budget church intended for the use of Indian workmen. ${ }^{73}$ It is built entirely of brick, with the exception, as at St Stephen's, of a substantial plinth, which is fashioned from an elegant Delhi quartzite (Fig. 12). This was a small but noteworthy difference from Shoosmith's building, and George had probably realized that the annual monsoon rains would splash salts against low courses of brickwork and cause it to decay rapidly, and that local quartzite was the ideal solution. The façade is punctuated with stepped entrance portals and blind arches in the upper reaches, and with a bold side-tower and prominent water chutes that cast long shadows on the brickwork. Unfortunately, and for unknown reasons, the building has fared poorly since construction. The tower has since been dramatically shortened and the nave walls broken up by rather unfortunate brick buttresses that were perhaps needed to counteract the weight of the main brick vault. The interior has survived better in its original condition. As Robert Grant Irving enthusiastically observed, 'no source of light was visible when looking up the nave' because the small windows which are recessed in the deep side-aisle arches are hidden from there, although they still let in enough light to allow a 'worshipper in any seat [to] read the fine print of a hymnal. ${ }^{74}$ This simple and functional building thus marks an important stage in George's developing career. Despite being firmly rooted in the classical tradition, and being 
indebted to Lutyens and even to Mughal traditions, it has a functional simplicity and lack of ornamentation that makes it, like Shoosmith's St Martin's, very much a 'modern’ building. In fact, it has even been labelled as a possible 'harbinger of modern architecture in India. ${ }^{75}$

St Stephen's College (1939-52), one of the constituent colleges of the University of Delhi, is George's largest and best known project. It would become the stylistic model for numerous other brick-built educational buildings in the 'university enclave' of north Delhi with central towers and long arcades (see Figs. $13 \& 14) .{ }^{76}$ St Stephen's is much admired by both western and Indian scholars, not least for its environmental sensitivity, good detailing, and attractive use of materials. ${ }^{77}$ For such a noteworthy project, therefore, it is remarkable that the college's architecture has never been related to the history of the institution and explained in these terms.

The foundation stone was laid, on 27 March 1939, by the Rev. Charles Freer Andrews, a close friend of Gandhi, a fellow of Pembroke College, Cambridge, and an unlikely but potent campaigner for Independence. ${ }^{78}$ Gandhi already had many connections with the College: he first visited St Stephen's in April 1915, and was to return on numerous occasions during the following years and speak to packed lecture rooms about his doctrine of non-violent non-cooperation. ${ }^{79}$ The college itself had started life as part of the Cambridge Brotherhood, an Anglican mission based at Westcott House, Cambridge (formed in 1877), and it had been the first in India to elect a native principal (Sushil Kumar Rudra), and also the first to gain independence (in 1912) from the Brotherhood's Mission Council. By 1927, it had severed its connections entirely, and at its fiftieth-anniversary celebrations, in 1931, it had proposed to make itself both 'more Christian and more Indian' - but not more British. ${ }^{80}$ Thereafter, a culture of political debate came to characterize the College, despite the fact that overt political activism was actively discouraged in India until as late as the 1940s, and this makes the college's decision to appoint an Anglo-Indian architect even more intriguing. ${ }^{81}$ It would have been possible, by the late 1930 s, to employ an 
Indian, but the fact that the college did otherwise suggests that George's reputation was such that he was seen, in spite of any possible political misgivings, as the best man for the job. ${ }^{82}$

During these years, the college continued to use its rather cramped premises near Kashmir Gate, designed in 1890 by Swinton Jacob (1841-1917), the principal exponent of 'Indo-Saracenic', or Mughal Revival architecture. ${ }^{83}$ Apart from its unsuitably small size, two further problems had been identified with Jacob's design. One was the terrible acoustics of the classrooms, which was attributed, rightly or wrongly, to the excessive use of stucco plaster, and which made it necessary to cover the ceilings with canvas and the floors with carpet. The second was the lack of a chapel on site, which meant that the college had to make use of an 'inadequate little chapel-room' at Maitland House nearby. ${ }^{84}$ There were, however, other shortcomings too. Thomas Metcalf, in his influential history of British architecture in India, has written that 'by its very nature IndoSaracenic was an architecture of façades', and it can be argued that much of Jacob's work was in essence ‘façadism' - in simply attaching a generalised Mughal façade to an otherwise 'modern' building. ${ }^{85}$ This is particularly the case with Jacob's design for St Stephen's College, where it appears that he paid too much attention to the façade and not enough to the interior, and to the uses required of it. George, in his new design for the College, would have been expected to take these matters very much on board.

George's new college buildings were completed in 1941, with the exception of the chapel, which was not built until $1952 .{ }^{86}$ The campus consists of four open courts in the Oxbridge fashion, with a detached chapel to the north. A series of groin-vaulted arcades connect the different courts, and gives access to the classrooms, hall, library and dining room. This layout, which has the principal façade facing south, is a deliberate reaction to the climate, and George later described how the classrooms were to be 'lighted from the north', thereby putting the corridors on the opposite side, and ensuring 'no direct sun, at any time of the day, in any month of the 
year, can penetrate, except through the door. ${ }^{87}$ In addition, the low height of most classrooms (compared with Jacob's building) and their often exposed brickwork must have helped improve the acoustics.

The buildings are mostly two and occasionally three stories in height except for the large corner chattris and the central tower. The principal façade is south-facing (see Fig. 13), with a tower that is remarkably similar to that of Shoosmith's St Martin's, although it also recalls Franke's HeiligKreuz-Kirchein at Gelsenkirchen (1927-29), and Giles Gilbert Scott's University Library at Cambridge (1931). At the base of the tower is a porch punctuated by a serliana and bracketed arches, both distilled and abstracted, just like St Thomas's. In line with George's growing appreciation of stream-lined architecture, the façades are almost entirely devoid of ornamentation, with the exception of small vents with jaali screens and an occasional fivepointed Star of India, rendered in brick, which the College adopted as part of its coat of arms in 1926. ${ }^{88}$ The principal façade achieves an attractive balance of horizontal and vertical elements. The horizontal emphasis is provided by the long arcades and the use of Delhi quartzite up to the springing point of the arches, which also provides an attractive contrast to the brickwork and the white stone string courses that run at two different levels. The vertical emphasis is, in turn, supplied by the central tower and the chattri towers at the sides. Similar themes are to be seen in the free-standing chapel (Fig. 15), which is built of brick with white-stone string courses and quartzite up to the arch of the doorway. The main façade has two broken pediments, both with George's characteristic circle motif at their outer edges. The source for this particular use of the circle motif is probably a Lutyens staircase in the Viceroy's House. The interior is whitewashed and simple, and one enters through a serliana supported by two fluted Doric columns that have circle motifs on their abacuses. 
The prominent place recently given to St Stephen's in a recent history of Delhi's 'modern architecture' is understandable. Its reputation, most of all, is due to its combination of a modern, unpretentious, vernacular manner of building with the mass, line and proportion of western (and in particular Lutyens-inspired) Classicism. It could be argued that the long arcades of the main college buildings, with their elegant vaulting, were a conscious application of George's earlier experience in Byzantine archaeology, although now combined with his interpretation of Lutyens's 'Elemental Mode'. As George himself said to Bagenal, his work could be labelled 'Primitive or Egyptian or Greek or Gothic or Renaissance or Hindu or Chinese, but it derives some from all [...] It does not represent anything but pure form, as dictated by the material'. ${ }^{89}$

From the early 1940s, George, who had for many years been levitating towards a pared-down, abstract aesthetic, turned to the principles of Modernism and embraced them more fully. We know from surviving correspondence and published articles that this shift in his outlook was heavily grounded in his own philosophical outlook, and with it too came a potent critique of Lutyens. For example, in a 1959 letter to Bagenal, he criticised what he perceived to be Lutyens's emphasis on appearance over function:

Lutyens could construct, but with him appearance took precedence, which I consider to be wrong. To him, the interior shell, and the outer shell [...] might be 6" or 6'0" so far as he was concerned, if it could be made to stand up. That is the inherent falsity of the whole procedure. Plan, Section, and then Elevation should be the order of thought $[\ldots]$ 'Elevation' is the flower and the last. ${ }^{90}$

This is consistent with a remark George made on Kashmir House in 1960, which was that the 'desired visual effects' controlled Lutyens's original design 'more than the plan'. ${ }^{91}$ Such criticism, with hindsight, seems unduly harsh and not entirely justified. ${ }^{92}$ However, it would be a mistake to think he had lost any of his admiration for Lutyens, or that his new-found interest in Modernism was without bounds, since, he certainly did not approve, for example, of the 'rejection of craftsmanship and tradition' that Modernism often entailed. ${ }^{93}$ 
In an earlier letter to Bagenal in 1959, he better explained his philosophy:

As you say, the Renaissance had a fault [...] which Lutyens shared. [...] It began at the wrong end with appearances, which absolutely [does not matter] so far as creation goes. Appearances, or beauty, is the end of a series of processes. [...] If any man should promise a client a beautiful building or beautiful picture, I would say he was presumptuous. [...] The Ruskinian and Keatsian equations of Beauty is Truth and Truth is Beauty simply will not work. [...] Pope was much nearer the match when he wrote: 'Beauty is Heaven's first law' [sic] [...]. If I were in England to-day I would not build necessarily in the Georgian style, nor in any historical style. [...] The matter is simple. The site. The climate. The material. The needs, etc. etc. will dictate what you ought to do. [...] Beauty (if it comes) will arrive out of the right handling of material, the human feeling of the furnace in which the whole has been fired, and many other feelings. ${ }^{94}$

What is being suggested here is a re-interpretation of Modernist aesthetics, where function comes first, and beauty, often a very different beauty to that in the Classical idiom, results from the 'pure form' of shapes and outlines, and the overt display of function. This marks a significant shift in George's approach to design The stuccoed 'Lutyens' dome of one of his early projects, Bhawalpur House, is in no way compatible with his new adopted philosophy. Somewhat closer is the austere nature of St Thomas's Church, or St Stephen's College, but closer still are his later works which will be discussed shortly.

In earlier correspondence with Anne Shearer, George connected his view of modern architecture with advances in science and technology, repeating Le Corbusier's view that in the Parthenon we can see:

the extreme care and more [the] technical proportion [...] that we give to our aeroplanes, and [our] engines [...] These huge column-drums were 'ground' [...] just as we grind in the tiny valves of our petrol engines, and the whole building was 'stream-lined' to please not only the physical eye, but the intellectual eye that asks for proportion, following a law [that] the universe undoubtedly has. ${ }^{95}$

Views such as this, which George expressed in private correspondence, were also to find a more public outlet in an article of 1951, entitled 'Indian Architecture: The Prospect Before Us'. There, 
he claimed that the Renaissance ended, after some 500 years, with Lutyens's Viceroy's House, and was critical of other buildings put up around the same time by his colleagues in Delhi (all of whom had by now left India). Connaught Place, the series of circular Classical colonnades in the centre of Delhi, which was planned by Lutyens but mostly designed by George's colleague Robert Russell, is called a 'backward-looking building':

Whether they look nice or not is a matter of opinion, but to a designer, there can be no question that the façade has controlled the building, to its detriment, and that more useful shops and living-quarters could be designed. The past has controlled the present. [...] I have called this a 'backward-looking building., ${ }^{96}$

'Forward-looking' architecture, however, did not escape his criticism either. In particular, he was wary of the importation of international architectural fashions into India without some adaptations to the climate of that country. He predicted that 'the impact of world-civilisation on India is going to be tremendous, far more so than the British occupation', and yet praised at length the use of reinforced concrete. He dismissed 'sham-modern' and 'half-modern' buildings which, he argued, simply swap brick for concrete, using exposed concrete façades and unnecessarily thick walls, before adding a warning, which some Indian architects could take stock of, that:

to copy the forms evolved on the Continent and in America will not do at all. Building-frontages entirely of glass and staircases enclosed in glass-houses are unthinkable in India. Here we have heat and glare to contend with, and anyone who adopts, with adapting, will burn his fingers. Climate will have its say. ${ }^{97}$

George's Sujan Singh Park Complex in Delhi (1942-45) reflects many of these new ideas. ${ }^{98}$ It is made up of two U-shaped ranges on either side of Cornwallis Road, creating the illusion of a closed square which, as Khanna has written, 'creates a sense of community - a feature not easy to find elsewhere in the capital. ${ }^{99}$ The design again betrays a range of influences. The large brickarch entranceways still have a definite feeling of Lutyens to them, but the Ambassador's Hotel in the northern range has a stocky paired-column carriage porch and Art-Deco-style balconies. At 
either side there are curved façades, undoubtedly a gesture to the stream-lined aesthetics of the time, and perhaps influenced by Franke’s Blumendelle housing project at Gelsenkirchen (1926), while the overall ensemble may itself have been influenced by other European housing schemes. While offering a new pared-down aesthetic in his works, George continued to use brick, and it is also possible to see vents with jaali screens just like those at St Stephen's, as well as pilasters ornamented with George's distinctive circle motif (Fig. 16). In his 1997 survey of Indian domestic architecture, Sarbjit Bahga praises these buildings highly, not only for the way the plan contends with the climate by allowing good cross-ventilation, but also the use of high ceilings, balconies, features all consistent with George's architectural philosophy. Also praised are the social benefits of creating a large, unified community space, which, unsurprisingly, has become a favoured address of many well-to-do Indians today. ${ }^{100}$

George continued to build throughout the 1950s. Two projects, both in south Delhi, that are particularly interesting are the Lodi Housing Colony (c. 1947) (Fig. 17) and the Tuberculosis Association of India Building, Red Cross Road (1950-52) (Fig. 18). The Lodi Colony, which has, in Jon Lang's opinion, a 'strikingly modernist touch', was built as refugee housing, and it is made up of three-story buildings with reinforced concrete hoods (as at Kashmir House), small windows, and arched entranceways. ${ }^{101}$ Each block contains four flats, with garden space at the front and back. As is important in Indian culture, the toilets and entranceways are situated some distance from the kitchen. ${ }^{102}$ The Tuberculosis Association Building (Fig. 18) had a rather less meagre budget, and offered George an opportunity to show how the Classical tradition could be combined with modernist forms. On the ground floor the open loggia combines lintels and arches, the springing points of which are decorated with cylindrical brackets, and the circle motif is picked up once again in the capitals of the detached lantern columns, like those used to support the serliana inside the chapel of St Stephen's College. Above this Classically-inspired loggia floats a grid of thoroughly modern lightweight horizontal louvers, made of concrete, 
moveable at the edges and centre, and fixed in between, with a thin concrete hood on the top of each. The main side-elevations are more uncompromising in having concrete louvers extending all the way across them, alternately fixed and moveable. Although now disfigured by bulky air conditioning units (not an unusual occurrence in Delhi), this building can perhaps serve as the clearest demonstration of George's various influences, and of his resolution of the conflicts between Classicism and Modernism. It is, as Stamp has said, 'rational modern architecture', always 'sensible and practical', and a suitable coda to George's career. ${ }^{103}$

These commissions suggest that George found a place for himself in the architectural world of post-Independence India, but more needs to be said about his involvement in increasingly native-dominated professional societies. With perhaps the notable exception of Claude Batley (1879-1956) in Bombay, very few British architects remained in India after 1947. ${ }^{104}$ In George's case, almost all the evidence suggests integration into these professional societies, and not marginalisation. A photograph taken at a seminar on landscape architecture in February 1958 shows George seated prominently in the centre, even though he was the only European present. ${ }^{105}$ An article from this same time introduces him as 'Shri Walter George', a small point perhaps, but an important one, as the title 'Shri' is the traditional Indian equivalent of 'Mr' and is a term of respect. ${ }^{106}$ This view is confirmed by his colleague Fernandes, who like George was involved in the Indian Institute of Architects, and who said:

Although [he] was an Englishman who prided himself on his outspokenness and was in truth often difficult to deal with, his great qualities outweighed his idiosyncrasies [... and] his Indian Colleagues continued to hold him in the highest respect. $^{107}$

However, it is hard to square this interpretation of his later life with more recent accounts that have described him rather uncritically as a 'colonial' architect, with all the negative connotations of this term, and have referred to his architecture (presumably including his Lodi Colony) as 'late 
imperial'. ${ }^{108}$ He was president of the Indian Institute of Architects in 1951-52 and again in 195758, and he also founded the Indian Institute of Town Planners. These were not simply honorary titles for an old man, and, in fact, the 1957-58 election to the Indian Institute of Architects was hotly contested. ${ }^{109}$ From this perspective, he emerges as a kind of public intellectual, writing 'The Prospect Before Us', proclaiming (perhaps prematurely) the end of the Renaissance, calling for architects to have more power in urban planning decisions, and for engineers and architects to collaborate more closely on social housing projects. ${ }^{110}$

George also took up the challenge to diversify education for Indian architects by founding the School of Architecture in Delhi (c. 1941) and running it (in an unofficial capacity) for ten years. Until that time, architectural education in India was heavily concentrated in Bombay, and particularly at the Sir J.J. School of Art, which had been founded in $1855 .{ }^{111}$ Transferring responsibility from Bombay was an important achievement and, in fact, George was the first President of the Indian Institute of Architects not to have come from that city. ${ }^{112}$ Thus, in embarking on this undertaking, he was presumably drawing on his own background at the Royal College of Art, and perhaps also on his awareness that neither Lutyens nor Scott had attended university. He is certainly reputed to have held the view that universities were the 'world's worst institutions for training architects'. ${ }^{113}$

George had also planned to write a thorough history of New Delhi, aware that his correspondence with Lutyens (and Baker) gave him a valuable personal archive to work from. However, he repeatedly delayed this project, offering once to send his archive to Bagenal so that he could undertake the work instead. Even despite being offered several 'financially attractive' incentives, he eventually abandoned the project, claiming that 'professional loyalties' prevented him, in particular, from writing about the battles between Lutyens and Baker. ${ }^{114}$ 'With him', Fernandes concluded, 'died the inside story of the unfortunate conflict between these two great 
men' ${ }^{115}$ We can still gain some hint of these matters, however, from his letters to Bagenal. One letter reads:

I kept in touch with both Baker and Lutyens until very shortly before each died. The last letter from Baker to myself ran to 6 or 8 pages, and bared his soul so nakedly that I never showed it to anyone, not even his wife, but often have in tired days considered to put it in the fire. The last letter from Lutyens was written by himself very shortly before he died, and ran much like this:

'My dear George,

Can I do anything to help you? Let me know if I can. Do what you can to see that the poorest are better housed. Make the rich pay for it by making them pay more for the lives they live.

Sincerely yours, ELL.'

but I have lost that letter. It was very unusual for Lutyens to write to any but his most intimate friends in his own hand. [...] Am I to introduce matter like this?... I think NOT, what do you think?... It is not in my make-up to do it. ${ }^{116}$

On another occasion he wrote:

'If some of [your] audience have worked in Lutyens' Office, they may be able to tell you all that I have written, and maybe more, but I doubt they can tell you what I have still to write., ${ }^{117}$

George's last few years were marked by increasingly eccentric behaviour, making the transcription of some of his letters difficult, which he often wrote late at night, his eyesight so poor he could hardly see what he was doing. ${ }^{118}$ He got Lutyens's birth date wrong by a decade when writing to Bagenal ('have you remembered the centenary? You have not mentioned it. Will you, or others, remember it in London?'). He then, embarrassingly, wrote a decade too early to Malcolm Mac-Donald, the High Commissioner for the United Kingdom in Delhi pleading for a centenary event to be held in Lutyens's honour. ${ }^{119}$ He received his C.B.E. when Queen Elizabeth visited Delhi in January 1961 but later in that year he fell ill. He died on 7 January 1962, aged 80, and was buried in Delhi's Nicholson Cemetery. ${ }^{120}$ It is not known what happened to his papers, or when his widow Lena died. 
George's position in the history of post-Independence Indian architecture needs to be much better recognised. Jon Lang, in a recent work on the subject, divides the practising architects into three categories: conservative Classically-trained architects (often British) who edged towards a modernist aesthetic, the Art Deco school and their Indo-Deco colleagues, and finally the Indians trained abroad (often in America) who came home and followed Le Corbusier. ${ }^{121}$ He also gives us a helpful indication of how Modernism was approached, dividing the cohort this time in two: those who took the style and tried to adapt it to the Indian climate and traditions, and those who simplified Art Deco exuberance to meet the 'demands' of the new aesthetic. ${ }^{122}$ It is clear that George fits into the first of both these categories: a strong believer in Classical, humanist architecture, who sought to make modernism work in India. While remaining faithful to the geometrical intricacy of Lutyens, and to the sculptural massing and use of materials of Scott and certain continental European architects, he gradually moved towards a kind of Modernism deriving from a Classical framework which, as Hussey has written, was 'gradually reduced or eliminated, retaining the elements and proportions'. ${ }^{123}$ This is not to say Lutyens's 'Elemental Mode' was itself some kind of Modernism but, rather, that George took it and 'revised' it, as Lutyens himself said. The 'George' style was the adaption of a revised 'Elemental Mode' to the Indian climate which considered such essential factors as materials, orientation, air circulation, and shading. He was fully aware of the new challenges that the built environment in his adopted country was to face, especially the rapid population growth of the 1940s-'60s, and the terrible displacement resulting from Partition - the world described in Manohar Malgonkar's $A$ Bend in the Ganges. ${ }^{124}$ There were no more Maharajahs' Houses to be built in Delhi; instead the challenges 
lay in high-density projects, refugee housing and less ceremonial architecture, and this was the challenge facing George that he so admirably met.

The success of so many of George's buildings, with perhaps the notable exception of the unfortunate St Thomas's, can be attributed to his attention to detail, which we saw had been earlier highlighted in the positive review he received for his archaeological study of Hagia Irene. Nowhere is this better seen than in the elegant use of brick and local quartzite at St Stephen's College. Indeed, one obituarist noted his diligence in such matters, as well as the individuality of his architecture, when remarking that:

Discerning architects have no difficulty in singling out a door, a surface of [...] brick or stone designed and executed by Walter George. [...] He had acquired [a] reputation of issuing as many as 800 drawings for a bungalow. ${ }^{125}$ George was, of course, not alone in bringing exposed brick to Delhi, or using it in the way he did. His colleague Shoosmith was in some ways more gifted, but he only built two buildings in India, a church (St Martin's) and a hostel, and provided no models in Delhi, as George did, for modern Indian architects concerned with education, social and private housing or public buildings. ${ }^{126}$ We should also note George's repeated use of certain decorative motifs, such as his adaption of the Doric order, and his curious circle motif. Whether on a capital, a bracket, or an abacus, it is hard not to see these circles as a subtle (even humorous) nod to Lutyens, who had himself used this same feature on some of his later City of London works, such as the Midland Bank (completed c. 1939).

The attention given to George in a recent and important history of Delhi's modern architecture will ensure, however, that his name continues to be known by architects and scholars. The style which he developed, marked by a sensitive and creative use of brick and an awareness of the climate and its dangers, has vast potential for architecture in India today. This has already been realised by some of those who have correctly identified the problems with erecting Western-style 
buildings in India and using unsuitable materials such as excesses of glass. The works of some recent architects, such as Charles Correa (born 1930), who have been much praised by modern scholars for recognising these difficulties, can be seen as descendants of the restrained, elegant style that George advocated (Fig. 19). Correa's citation for the R.I.B.A. Gold Medal he won in 1984 included praise for avoiding the insensitive imposition of inappropriate western forms of building' in India. ${ }^{127}$ This approach is very different from that taken by other architects, such as Le Corbusier whose works at Chandigarh, the new capital for the Punjab, have been said to show 'no appreciable effort to accommodate the country's climate' and require high energy inputs in order to function. ${ }^{128}$ There is perhaps no greater contrast in the history of Indian architecture immediately before and after Independence than that of the concrete megalomania of Chandigarh and the elemental simplicity of George's St Stephen's College.

\footnotetext{
${ }^{1}$ R.I.B.A. Prints and Drawings Room (Victoria and Albert Museum), Hope Bagenal papers, BaHo/1/3, p. 1: Walter George to Hope Bagenal, 14 Jan. 1959.

${ }^{2}$ R.I.B.A. (Portland Place), Walter George Biographical File, J. B. Fernandes, 'Obituary: Walter George’, p. 1 and T. J. Manickam, 'Obituary: Walter Sykes George', p. 1. Also, anon., 'Obituary: Walter Sykes George', Urban and Rural Planning Thought (Feb. 1962), pp. 1-2.

${ }^{3}$ Rahul Khanna, The Modern Architecture of New Delhi (Noida, 2008), pp. 20-27. Gavin Stamp, 'Indian Summer', Architectural Review, 159 (Jun. 1976), pp. 365-66, Gavin Stamp, 'British Architecture in India', Journal of the Royal Society of Arts, 129 (May 1981), p. 376, Gavin Stamp, 'India: end of the classical tradition', Lotus International, 34 (1982), pp. 80-81 and Gavin Stamp, 'Lutyens, India, and the Future of Architecture', Lutyens Abroad, ed. Andrew Hopkins and Gavin Stamp (London, 2002), pp. 195-96.

${ }^{4}$ Philip Davies, Splendours of the Raj (London, 1985), pp. 235, 236 and 241.

${ }^{5}$ R.I.B.A. (Portland Place), Walter George papers, Fernandes, 'Obituary', p. 2; and Robert Byron, 'New Delhi', Architectural Review, 69 (Jan. 1931), p. 13.
} 
${ }^{6}$ R.I.B.A. Prints and Drawings Room (Victoria and Albert Museum), Walter George papers, GeW/1/9, p. 1: Walter George to Anne Shearer, 14 Mar. 1952.

7 Stamp, Lutyens Abroad, p. 191.

${ }^{8}$ R.I.B.A. Prints and Drawings Room (Victoria and Albert Museum), Hope Bagenal papers, BaHo/1/3, p. 1: Walter George to Hope Bagenal, 2 Jan. 1959. R.I.B.A. (Portland Place), Walter George Biographical File, Admission Statement as a Fellow of the R.I.B.A., 7 Feb. 1929.

${ }^{9}$ See Robin Cormack, The Church of Saint Demetrios in Thessaloniki: The Watercolours and Drawings of W.S. George (Thessaloniki, 1985) and Scholars, Travels, Archives: Greek History and Culture Through the British School at Athens, ed. Michael Llewellyn Smith, Paschalis M. Kitromilides and Eleni Calligas (Athens, 2009), pp. 13543.

${ }^{10}$ R.I.B.A. Prints and Drawings Room (Victoria and Albert Museum), PB361/19: 'Afterglow: the Acropolis, Athens'. The mezzotint was given to the R.I.B.A. by Shearer in 1985; see Jane Johnson and Alan Greutzner, The Dictionary of British Artists (Woodbridge, 1976), p. 196.

${ }^{11}$ R.I.B.A. Prints and Drawings Room (Victoria and Albert Museum), Walter George papers, GeW/1/9, p. 3: George to Shearer, 14 Mar. 1952.

${ }^{12}$ See Walter George, The Church of Saint Eirene at Constantinople (London, 1912).

13 A.L.P., 'Review', The Burlington Magazine, 23, 122 (May 1913), p. 116.

${ }^{14}$ R.I.B.A. Prints and Drawings Room (Victoria and Albert Museum), Walter George papers, GeW/1/9, p. 6: George to Shearer, 14 Mar. 1952.

${ }^{15}$ Nikolaus Pevsner, Ian Nairn and Bridget Cherry, The Buildings of England: Surrey (Harmondsworth, 1971), p. 520.

16 Ibid.

17 William Godfrey Newton, The Work of Emest Newton, R.A., Containing a List of His Works (London, 1925), pp. 186-87.

${ }_{18}$ R.I.B.A. Prints and Drawings Room (Victoria and Albert Museum), Walter George papers, GeW/4, 'Specifications of works for twelve cottages, of three types, to be erected at Whiteley Park, Burhill, Surrey', Jun. 1914.

${ }^{19}$ R.I.B.A. (Portland Place), Walter George papers, Fernandes, 'Obituary’, p. 1. 
${ }^{20}$ R.I.B.A. (Portland Place), Walter George papers, R.I.B.A. Admissions Statement. George refers to himself as Baker's 'Resident Architect'. Baker for his part does not mention any of his Delhi representatives in his autobiography, but in the Herbert Baker Papers at the R.I.B.A. Prints and Drawings Room (Victoria and Albert Museum), there is a letter in which he refers to George as 'my representative whom I leave behind'; see BaH/2/1/13, folio ii: Baker to Sir Malcolm Hailey, 18 Mar. 1916. See also Herbert Baker Papers, $\mathrm{BaH} / 2 / 2 / 53$, folio ix, 'Memorandum of my relations with Lutyens and Delhi written on the S.S. 'Viceroy of India', Feb-March 1931'.

${ }^{21}$ J.B. Fernandes, 'Obituary: Walter George’, Journal of the Indian Institute of Architects, 27,3 (Jul.-Sept. 1961), p. 3.

${ }^{22}$ Stamp, 'End of the Classical Tradition', pp. 75-77.

${ }^{23}$ Stamp, 'Indian Summer', pp. 367-69.

${ }^{24}$ Stamp, 'End of the Classical Tradition', p. 69. In the Lutyens Papers at the R.I.B.A. Prints and Drawings Room (Victoria and Albert Museum), there are some letters from Lutyens to Lady Emily Lutyens in which George is mentioned. Two are relevant here. In the first Lutyens mentions dining with 'Hall, Greaves, W.S. George and Walpole', those who were 'in the office', on a Saturday evening in December 1917; see LuE/16/1/1, folio iii: Lutyens to Lady Emily, 3 Jan. 1917. The second is an endearing description of his $48^{\text {th }}$ birthday later in 1917 in which he writes that 'the office boys George, Greaves, Walgate, Hall, Brandon [and] Blomfield' dressed up in suits and top hats and sung him songs. 'Glees and jollies', he writes, ' 44 of us sat down to dinner. I had a cake with 48 candles. The night was lovely, warm and a new moon sky high'; see Lutyens Papers, LuE/16/3/5, folio vi: Edwin Lutyens to Lady Emily, 1 Apr. 1917.

${ }^{25}$ Herbert Baker, Architecture and Personalities (London, 1944), p. 36.

${ }^{26}$ R.I.B.A. (Portland Place), Walter George papers, Fernandes, 'Obituary', p. 1. For their later careers, see Stamp, 'Indian Summer', p. 372 and Stamp, Lutyens Abroad, p. 200.

${ }^{27}$ Edward Morgan Forster, A Passage to India (Harmondsworth, 1961), p. 111.

${ }^{28}$ Geoffrey Scott, The Architecture of Humanism (London, 1914).

${ }^{29}$ Byron, 'New Delhi', p. 6 and Plate VII. 
${ }^{30}$ R.I.B.A. Prints and Drawings Room (Victoria and Albert Museum), Hope Bagenal papers, BaHo/1/3, p. 2: Walter George to Hope Bagenal, 2 Jan. 1959.

${ }^{31}$ Patrick Bowe, “The Genius of an Artist”, Garden History, 37, 1 (Summer 2009), p. 68.

32 Walter George, 'The Roadside Planting of Lutyens' New Delhi', Urban and Rural Planning Thought (Apr. 1958), p. 84, Bowe, “"The Genius of an Artist”, p. 71 and Colin Amery in Lutyens, ed. Colin Amery et al. (London, 1981), p. 174. While it might be expected that Lutyens would have worked with his assistant Shoosmith, and not George, the roadside planting work had been underway for more than a year by the time the former arrived in Delhi.

${ }^{33}$ Bowe, "The Genius of an Artist", p. 71.

${ }^{34}$ R.I.B.A. (Portland Place), Walter George papers, R.I.B.A. Admissions Statement.

${ }^{35}$ Henry Medd, 'Obituary: Walter Sykes George', Journal of the Royal Institute of British Architects, 69 (Mar. 1962), p. 102.

${ }^{36}$ R.I.B.A. (Portland Place), Walter George papers, R.I.B.A. Admissions Statement; Medd, 'Obituary', p. 102.

${ }^{37}$ Ibid.

${ }^{38}$ Byron, 'New Delhi', p. 18.

${ }^{39}$ R.I.B.A. (Portland Place), Walter George papers, Fernandes, ‘Obituary’, p. 2.

${ }^{40}$ Ibid.

${ }^{41}$ R.I.B.A. Prints and Drawings Room (Victoria and Albert Museum), Hope Bagenal papers, BaHo/1/3, p. 2: Walter George to Hope Bagenal, 2 Jan. 1959; Roger Gradidge, Lutyens Abroad, p. 158, Mary Lutyens, Edwin Lutyens (London, 1980), p. 189 and Gavin Stamp, 'Edwin Lutyens', in the Macmillan Encyclopedia of Architects, ed. Adolph Placzek (London, 1982), p. 46.

${ }^{42}$ Christopher Hussey, The Life of Sir Edwin Lutyens (London, 1953), p. 462.

${ }^{43}$ R.I.B.A. Prints and Drawings Room (Victoria and Albert Museum), Hope Bagenal papers, BaHo/1/3, p. 2: Walter George to Hope Bagenal, 2 Jan. 1959.

${ }^{44}$ R.I.B.A. Prints and Drawings Room (Victoria and Albert Museum), Hope Bagenal papers, BaHo/1/3, pp. 1-2: Walter George to Hope Bagenal, 14 Jan. 1959. 
${ }^{45}$ R.I.B.A. Prints and Drawings Room (Victoria and Albert Museum), Walter George papers, GeW/1/9, pp. 3-4: George to Shearer, 14 Mar. 1952; and Rudolf Wittkower, Architectural Principles in the Age of Humanism, 5th edn (Chichester, 1998), pp. 145-47.

${ }^{46}$ R.I.B.A. (Portland Place), Walter George papers, Fernandes, ‘Obituary’, p. 1.

${ }^{47}$ Stamp, 'Sir Edwin Lutyens', p. 47 and George, 'The Roadside Planting of Lutyens' New Delhi', p. 81.

48 Stamp, 'Indian Summer', pp. 368 and 371.

${ }^{49}$ R.I.B.A. Prints and Drawings Room (Victoria and Albert Museum), Hope Bagenal papers, BaHo/1/3, p. 9: Walter George to Hope Bagenal, 2 Jan. 1959. His use of 'aniconic' is unusual - meaning perhaps an absence of ornamentation.

${ }^{50}$ R.I.B.A. (Portland Place), Walter George papers, R.I.B.A. Admissions Statement.

${ }^{51}$ Byron, 'New Delhi’, pp. 13-14.

52 Not to be confused with the 1919 and 1922 designs by Lutyens for a house for the Maharajah of Kashmir (both unexecuted). See R.I.B.A. Prints and Drawings Room (Victoria and Albert Museum), Edwin Lutyens papers, LuE/18/5/4: Lutyens to Lady Emily, 20 Feb. 1922; and Stamp, Lutyens, Hayward Gallery cat., p. 181. Prithviraj was a twelfth-century Hindu king.

${ }^{53}$ Walter George, 'The Architecture of Walter George', Design (Bombay) (Sept. 1960), p. 21.

${ }^{54}$ Ibid., p. 20.

${ }^{55}$ Sarbjit Bahga, Surinder Bahga and Yashinder Bahga, Modern Architecture in India (New Delhi, 1993), p. 7.

${ }^{56}$ George, 'The Architecture of Walter George’, p. 21.

${ }^{57}$ R.I.B.A. Prints and Drawings Room (Victoria and Albert Museum), Edwin Lutyens papers, LuE/19/12/7, folios ii and iii: Lutyens to Lady Emily, 14 Feb. 1929.

${ }^{58}$ George, 'The Architecture of Walter George', p. 20.

${ }^{59}$ Ibid., p. 21.

${ }^{60}$ Ibid. George may have been referring to Wright's Robie House, Illinois (c. 1909).

${ }^{61}$ Walter George, 'Indian Architecture: The Prospect Before Us', Journal of the Indian Institute of Architects, 17, 1 (Jan.-Mar. 1951), p. 4.

${ }^{62}$ Robert Grant Irving, Indian Summer: Lutyens, Baker, and Imperial Delhi (New Haven and London, 1981), fig. 197. 
${ }^{63}$ George, 'The Architecture of Walter George', p. 21.

${ }^{64}$ R.I.B.A. (Portland Place), Walter George papers, Fernandes, 'Obituary', p. 2.

${ }^{65}$ Kazi Khaleed Ashraf and James Belluardo (eds.), An Architecture of Independence: The Making of Modern South Asia (New York, 1998), p. 11.

${ }^{66}$ Nikolaus Pevsner, An Outline of European Architecture (Penguin, 1964), pp. 404-09; Dennis Sharp, Twentieth Century Architecture (London, 1991), p. 114; and Wolfgang Pehnt, Expressionist Architecture (London, 1973), p. 198.

${ }^{67}$ Sharp, Twentieth Century Architecture, p. 112.

${ }^{68}$ Pehnt, Expressionist Arcbitecture, p. 162.

${ }^{69}$ Medd ('Obituary', p. 102) states that George designed two hospitals in Jodhpur: the earlier 1924 building (noted in his R.I.B.A. Admissions Statement) and the c. 1930 Umaid Hospital (here discussed). The Umed Club was founded in 1922 by the Maharajah of Jodhpur, and is still active today.

${ }^{70}$ Benjamin Rowland, The Art and Architecture of India (Penguin, 1953), pp. 132-34.

${ }^{71}$ Stamp, in Lutyens, ed. Amery, p. 184. The building is not to be confused with Oscar Pereira's St Thomas's (1971-73) also in Delhi.

${ }^{72}$ Gavin Stamp, ‘Arthur Gordon Shoosmith’ in Oxford Dictionary of National Biography, ed. Colin Matthew and Brian Harrison (Oxford, 2004), p. 415.

${ }^{73}$ Irving, Indian Summer, p. 331.

${ }^{74}$ Ibid., p. 334.

${ }^{75}$ Bahga, Modern Architecture in India, p. 7 and Jon Lang, Madhavi Desai and Miki Desai, Architecture and Independence: The Search for Identity. India 1880-1980 (Oxford, 1997), p. 159.

76 Ashok Jaitly, St Stephen's College (New Delhi, 2006), p. 36.

${ }^{77}$ Khanna, The Modern Architecture of New Delhi, p. 20 and Stamp, Lutyens Abroad, p. 196.

${ }^{78}$ Jaitly, St Stephen's College, p. 35.

${ }^{79}$ Ibid., pp. 20-21.

${ }^{80}$ Francis Fitzhugh Monk, A History of St Stephen's College, Delhi (Calcutta, 1935), pp. 2, 112, 149, 228-29 and 240 .

${ }^{81}$ Jaitly, St Stephen's College, p. 38 and 47. 
${ }^{82}$ Lang, Desai and Desai, Architecture and Independence, p. 140.

${ }^{83}$ Monk, A History of St Stephen's College, p. 39.

${ }^{84}$ Ibid., pp. 46 and 239.

85 Thomas Metcalf, An Imperial Vision: Indian Architecture and Britain's Raj (London, 1989), p. 245.

${ }^{86}$ Jaitly, St Stephen's College, pp. 36-37 and Monk, A History of St Stephen's College, p. 184. A plaque, inscribed 'Allnutt Hostel 1922', is now confusingly attached to part of George's building. It must have been removed from the original hostel, which was a neo-Classical structure located elsewhere in the city.

${ }^{87}$ George, 'Indian Architecture: The Prospect Before Us', p. 4.

${ }^{88}$ Jaitly, St Stephen's College, p. 5.

${ }^{89}$ R.I.B.A. Prints and Drawings Room (Victoria and Albert Museum), Hope Bagenal papers, BaHo/1/3, pp. 8-9: Walter George to Hope Bagenal, 2 Jan. 1959.

${ }^{90}$ R.I.B.A. Prints and Drawings Room (Victoria and Albert Museum), Hope Bagenal papers, BaHo/1/3, p. 2: Walter George to Hope Bagenal, 14 Jan. 1959.

${ }^{91}$ George, 'The Architecture of Walter George', p. 20.

${ }_{92}^{2}$ R.I.B.A. Prints and Drawings Room (Victoria and Albert Museum), Hope Bagenal papers, BaHo/1/3, pp. 4-5: Walter George to Hope Bagenal, 2 Jan. 1959.

${ }^{93}$ George thought Lutyens's style would stage a comeback; see R.I.B.A. Prints and Drawings Room (Victoria and Albert Museum), Hope Bagenal papers, BaHo/1/3, pp. 2-3: Walter George to Hope Bagenal, 2 Jan. 1959. Lutyens's views were well known, see Edwin Lutyens, 'What I Think of Modern Architecture', Country Life (20 Jun. 1931), pp. 775-77.

${ }^{94}$ R.I.B.A. Prints and Drawings Room (Victoria and Albert Museum), Hope Bagenal papers, BaHo/1/3, pp. 3-4 and 8: Walter George to Hope Bagenal, 2 Jan. 1959. George's interpretation of Ruskin is questionable, of Keats less so, and of Pope mistaken; see John Ruskin, Modern Painters (London, 1856), II, pp. 28-35 and III, p. 33; John Keats, 'Ode to a Grecian Urn', The Poetical Works of John Keats, ed. H.W. Garrod (Oxford, 1939), p. 262; and Alexander Pope, 'An Essay on Man to Lord Bolingbroke', Epistle IV, 49, in Pope: Poetical Works, ed. H. Davis (Oxford, 1966), p. 270. 
${ }^{95}$ R.I.B.A. Prints and Drawings Room (Victoria and Albert Museum), Walter George papers, GeW/1/9, pp. 3-4: Walter George to Anne Shearer, 14 Mar. 1952. Le Corbusier, Towards a New Architecture, trans. Frederick Etchells (London, 1963), p. 125.

${ }^{96}$ George, 'Indian Architecture: The Prospect Before Us’, p. 3.

${ }^{97}$ Ibid., p. 4.

${ }^{98}$ Sujan Singh was the father of Sobha Singh, for whom George had designed a house (Baikunth, no. 1)

on Janpath road in Delhi (1934-35).

${ }^{99}$ Khanna, The Modern Architecture of New Delbi, p. 24.

100 Sarbjit Bahga, Surinder Bahga and Yashinder Bahga, New Indian Homes: An Architectural Renaissance (New Delhi, 1997), p. 4.

${ }^{101}$ Jon Lang, A Concise History of Modern Architecture in India (Delhi, 2002), p. 33.

102 'Architecture of Delhi: From Housing Colonies to Apartment Blocks' at delhiarchitecture.weebly.com/housing-sector.html, retrieved 3 April 2012.

${ }^{103}$ Stamp, 'End of the Classical Tradition', p. 79.

${ }^{104}$ Lang, Desai and Desai, Architecture and Independence, p. 141.

105 D. N. Chaudhuri, 'A Group Photograph', Urban and Rural Planning Thought, 1, 2 (Apr. 1958).

${ }^{106}$ George, 'The Roadside Planting of Lutyens’ New Delhi', p. 90.

${ }_{107}$ R.I.B.A. (Portland Place), Walter George papers, Fernandes, 'Obituary', p. 1.

108 Ashraf and Belluardo, An Architecture of Independence, p. 11.

${ }^{109}$ R.I.B.A. (Portland Place), Walter George papers, Fernandes, ‘Obituary’, p. 2.

${ }^{110}$ George, 'Indian Architecture: The Prospect Before Us', p.11 and anon, 'Town Planning', Civic Affairs, 6, 4 (Nov. 1958), p. 61.

${ }^{111}$ Lang, A Concise History of Modern Architecture in India, p. 8 and Christopher London, Bombay Gothic (Mumbai, 2002), p 20.

112 Anon, 'Obituary', Indian Architect, p. 35; and R.I.B.A. (Portland Place), Walter George papers, Manickam, ‘Obituary', p. 1.

113 Anon., 'Growth of Architectural Practice in India', The Indian Architect, 11, 1 (Jan. 1969), p. 32. 
${ }^{114}$ R.I.B.A. (Portland Place), Walter George papers, Fernandes, ‘Obituary', pp. 1-2. R.I.B.A. Prints and Drawings Room (Victoria and Albert Museum), Hope Bagenal papers, BaHo/1/3, pp. 5-8: Walter George to Hope Bagenal, 2 Jan. 1959; anon., 'The Building of New Delhi', The Times (8 Jan. 1962). 115 R.I.B.A. (Portland Place), Walter George papers, Fernandes, ‘Obituary’, p. 1.

116 R.I.B.A. Prints and Drawings Room (Victoria and Albert Museum), Hope Bagenal papers, BaHo/1/3, pp. 6-7: Walter George to Hope Bagenal, 2 Jan. 1959.

117 R.I.B.A. Prints and Drawings Room (Victoria and Albert Museum), Hope Bagenal papers, BaHo/1/3, p. 2: Walter George to Hope Bagenal, 14 Jan. 1959.

118 Ibid., p. 1.

${ }^{119}$ R.I.B.A. Prints and Drawings Room (Victoria and Albert Museum), Hope Bagenal papers, BaHo/1/3, p. 1: Walter George to Hope Bagenal, 16 Jan. 1959; and BaHo/1/3, pp. 1-2: Walter George to Malcolm Mac-Donald, 16 Jan. 1959.

${ }^{120}$ R.I.B.A. (Portland Place), Walter George papers, Fernandes, ‘Obituary', p. 1.

${ }^{121}$ Lang, A Concise History of Modern Architecture in India, pp. 1-33.

122 Ibid.

${ }^{123}$ Hussey, The Life of Sir Edwin Lutyens, p. 462.

${ }^{124}$ Jaitly, St Stephen's College, p. 39.

125 Anon., 'Obituary', Indian Architect, p. 35.

${ }^{126}$ Stamp, 'Indian Summer', p. 371.

${ }^{127}$ Norma Evenson, The Indian Metropolis: A View Towards the West (New Haven and London, 1989), p. 224.

${ }^{128}$ Ibid., pp. 229-30; Metcalf, An Imperial Vision, p. 250. 